\title{
Emotional Appeals are used in Social Advertising: Content Analysis on Turkish Case
}

\author{
Rasime Ayhan Yılmaz, Anadolu University, Turkey \\ Mesude Canan Ozturk, Anadolu University, Turkey
}

\begin{abstract}
Advertisements appear as the most effective means of announcing the social campaigns and projects. The advertisements with social dimension are the very first of the communication attempts performed for the purpose of informing society about social issues and creating changes in their beliefs and attitudes. The purpose of this study is to reveal the creative contents used in social advertisements in Turkey. The scope of the study consists of printed social advertisements, which are awarded Crystal Apple given annually by Turkish Association of Advertising Agency. The chosen advertisements were investigated under 8 categories including the subject of the advertisements, execution strategy, types of execution, message tone, choice of words, formats, communication of advertised company/brand and advertising appeals.
\end{abstract}

Keywords: Emotional Appeals, Social Advertising, Execution Strategies, Message Tone, Advertising Formats. 


\section{Introduction}

We can see that the social advertisements having a gradual increase in number attempt to take people's attention to various issues such as education, health and environment. These social advertisements may not only vary depending on the advertisers but they may also differ in their methods of application. When we consider the advertisements with social dimensions from the perspective of advertisers, examples include the state authorities, non-governmental organizations and private establishments. We see that private establishments generally undertake communication sponsorship of social campaigns conducted by non-governmental organizations (Öztürk, 2009).

Many non-governmental organizations in Turkey perform various activities in accordance with the purpose of organization and they sometimes launch some specific campaigns to take society's attention to some certain issues, and thus they contribute to the solution of these issues. However, they have to fulfill some specific communication activities for this purpose. They have to utilize some mass communication tools to let a substantial mass of people hear about their practices. They largely achieve it using advertisements with social dimension. Use of mass communication tools always has a tremendous cost. In their communication attempts, non-governmental organizations perform joint campaigns with private establishments to afford this cost. Establishments should perform pre-planned and purposeful communications in their corporate responsibilities for their stakeholders. The communication attempts performed within the scope of CSR should not only contain the public relations and communication attempts but also interactive web pages and face to face introduction of their administrators (O’Connora, Shumateb, and Meister, 2008).

\section{Social Advertisement}

The concept of advertisement with social dimension involves the social advertisements within the scope of social marketing and the other advertisements within the scope of social initiative practices. The advertisements with social dimensions used in the social initiative practices of private establishments often appear as corporate advertisements. These can be perceived as communication studies to enrich the reputation and image of the corporate rather than introducing the corporate and its products. (Drumwrigth\&Murhpy, 2001). The advertisements which aim to persuade audiences about social issues should be very carefully addressed. In many cases, people are asked not to do some certain things. Here, motivation triggers are 
required which shall lead them doing right thing rather than stopping them to do something. Advertisements are considered as effective means in increasing social awareness (Kaptan, 2003). In such campaigns, the mass communication means play significant roles in creating changes in awareness and attitudes. "Based on the social marketing approach, social campaigns should be prepared considering the social marketing concepts and techniques so as to be successful" (Gürgen, 1987). Therefore, there is need for effective communication methods in advertisements with social dimensions. Accordingly, it is very significant to utilize the methods used in advertisements with commercial interest also in the advertisements with social purposes.

\section{The Execution Strategies}

When we examine advertisements, it appears that what is told in the advertisement is as important as how it is told. Therefore, the persuasion strategies need to be used in communication studies to create expected behavior changes in the target audience. Therefore, appeal should be primarily handled in execution strategies.

\section{Emotional Advertising Appeals}

Belch \& Belch (1995) defines appeals as an approach used in attracting attentions of or affecting emotions of consumers about certain products, services or events. On the other hand, Berkman and Gilson (1987) define appeals as influencing attitudes towards certain products or services or as creative attempts used in motivating consumers about some certain activities. Davies (1993), Wells, Burnet \& Moriarty (2000), Lane \&Russel (2005) and Moriarty (1991) relate appeals with the benefits of products, their characteristics, incentives or requirements. Appeal is majorly divided into two as rational and emotional. Rational appeals offer the desired benefits such as ones related to personal interest, the quality of products, whether the product is economical or not, its value and performance (Manrai, Broach, Manrai, 1992).

Emotional appeals include ones which attempt to activate positive or negative feelings to motivate purchasing (Manrai, Broach \&Manrai 1992). This type of appeals contains various emotions leading people towards doing or not doing something.

Beetinghouse\&Cody (1987) define emotional appeals as ones attempting to convince receivers to sense some emotions, such as love, joy, hope, excitement, fear, anger, embarrassment, courage, refusal, warmth, nostalgia, happiness. 
This study is limited to emotional appeals among all types of appeals.

Except appeals, Kotler\&Lane (2005) lists execution styles used in social advertisements as follows:

1- A slice of life

2- Lifestyle (availability of the people as models with their lifestyles (sport men-artists)

3- Fantasy (Fantastic creatures or fantastic looks)

4- Mood or image (a smoker who has a hole in the throat or a 10-year girls smoking)

5- Musical (giving poetic messages, such as lyrics)

6- Personal symbols (campaign characters)

7- Technical expertise (the look of smoking people)

8- Scientific evidence (statistics, e.g. How many cardiac patients there are)

9- Testimonial or endorsement (the share of experiences)

These styles can be used individually or in combination. Except above details, the decisions which may possibly be additionally used in social advertisements are as follows (Kotler\&Lane 2005): The tone of the message is very significant. The message may be serious, lighthearted and straightforward. Moreover, characteristics of the words and the copy used in social advertisements should also be paid attention. The campaign name or program name, slogans, taglines and copy (text) should be oriented towards purposes. Particularly, care should be taken that slogans and tagline are simple and understandable. Moreover, the stylistic features of social advertisements are also included in execution decision: illustrations, layout, graphics, colors and photographs should be handled very carefully.

\section{The Purpose of the Study}

The purpose of this study is to reveal out the creative contents used in social advertisements. For this purpose, efforts were made to answer following research questions:

1. What are the subjects of the social advertisements?

2. The creative execution used in social advertisements:
a. Types of execution style
b. Message tone
c. Choice of words
d. Format 
e. The structure, level and type of emotional appeal

3. What is the communication of advertised company/brand in social advertisements?

\section{The Research Method}

This is a field research. The research type is a study approach which aims to describe an existing case or a case existed in the past in a plain manner(Karasar, 2002). Content analysis is performed since the study is based on content examination of creative execution used in social advertisements.

\section{The Scope and the Sampling}

The study sample consists of printed social advertisements awarded which are called as Crystal Apple annually given by Turkish Association of Advertising Agency. Totally, 52 printed advertisements published inhttp://www.kristalelma.org.tr/tarihce.html, where all awards covering 21 years (1989-2009) are included, were examined and 6 of those advertisements were excluded from the category of social advertisement. Content analysis included the remaining 46 advertisements.

\section{Coding}

The advertisements chosen were examined under 8 categories including subject of the advertisement,execution strategy, types of execution, message tone, choice of words, formats, communication of advertised company/product, advertising appeals.

Among those categories, advertising appeals were adapted from the study of Y1lmaz (1999) titled, "DuygusalÇekicilikliReklamlarınIlletişimEtkileri (The Communication Effects of the Advertisements with Emotional Appeals) and the creative executions were adapted from the study of Kotler, Roberto \& Lee (2002). Each advertisement was coded considering the above mentioned categories and the sub-categories. If an advertisement appeared convenient for more than one sub-category, it was included in these categories as well.

\section{Coding Categories}

1. Fear appeal: An emotional reaction against a threat or at least an implied threat.

2. Guilt appeal: The regret, self-blame and guilt felt due to violation of a valued behavior. It occurs as a consequence of not acting in an ethically, morally and socially 
advised behavior.The sense of quilt and self-blame felt by those who do not respect the environment and the nature.

Reactive guilt: The reaction against the violation of an acceptable behavior (lessening the quilt of a man, who forgot the wedding anniversary and caused sadness in part of his wife, by buying the product in an advertisement)

Anticipatory quilt: The guilt felt when people assume the violation of an internalized behavior. The investment by investment companies to family life considering the well-being of children in the future.

The existential guilt.The sense of the gap between one's welfare and that of others'.The campaigns requesting monetary grant.

3. Provocation: On the contrary to others, indefinite and violating the cultural and social taboos.

4. Warmth: The positive and moderate sense resulted from love, family, friendship, sensibility, children, feeling good, child-mother interaction, holiday settings and fantasy characters.

5. Humor: The stimulus expected to lead to joke and/or fun.

6. Nostalgia: The desire to good things experienced in the past. Preferring objects which were more common in adolescence.

7. Sexual appeal: A type of appeal including nudity, sexual relationship and sexual imply.

The data as a consequence of coding was submitted to SPSS program for frequency analysis.

\section{Findings and Discussion}

Totally, 46 printed social advertisements were analyzed in the study. Among them, (89\%) were prepared by non-governmental organizations and (11\%) were prepared by commercial establishments.

\section{Subjects of social advertisements}

When we examine the distribution of the subjects of social advertisements analyzed in this study, it was observed that the subjects of environment $(23.9 \%)$, street child $(23.9 \%)$ and health $(17.4 \%)$ are more prominent (Table 1$)$. 
Table 1: Distribution of Social Subjects in Social Advertisements

\begin{tabular}{lrr}
\hline Subject of Social Ads & Frequency & $\%$ \\
\hline environment & 11 & 23,9 \\
education & 5 & 10,9 \\
economic crisis & 2 & 4,3 \\
animals rights & 3 & 6,5 \\
human rights & 2 & 4,3 \\
health & 8 & 17,4 \\
disarmament & 1 & 2,2 \\
art & 2 & 4,3 \\
street child & 11 & 23,9 \\
violence & 1 & 2,2 \\
Total & 46 & 100,0 \\
\hline
\end{tabular}

\section{Creative execution}

The sub-categories investigated under title of creative execution used in social advertisements are as follows: Execution strategy, types of execution, message tone, choice of words, format and the structure, level and type of emotional appeal.

Table 2: Distribution of Execution Styles in Social Advertisements

\begin{tabular}{lcccc}
\hline Execution Styles & \multicolumn{2}{c}{ Non-exist } & \multicolumn{2}{c}{ Exist } \\
\hline \multirow{2}{*}{ Slice of Life } & Frequency & $\%$ & Frequency & $\%$ \\
Lifestyle & 11 & 23,9 & 35 & 76,1 \\
Fantasy & 45 & 2,2 & 45 & 97,8 \\
Mood or image & 34 & 73,9 & 12 & 26,1 \\
Poetic & 13 & 28,3 & 33 & 71,7 \\
TechnicalExpertise & 44 & 95,7 & 2 & 4,3 \\
Testimonial & 40 & 87 & 6 & 13 \\
\hline
\end{tabular}


When we examined the social advertisements with regards the inclusion of execution styles, it was found that lifestyle (97.8\%) was most frequently preferred followed by slice of life (76.1\%) and mood/image (71.7\%) ( Table 2).

\section{a. Message tone}

Table 3: Distribution of Message Tone in Social Advertisements

\begin{tabular}{lcccc}
\hline Message Tone & Non-exist & \multicolumn{3}{l}{ Exist } \\
\hline & Frequency & $\%$ & Frequency & $\%$ \\
Serious & 6 & 13 & 40 & 87 \\
Lighthearted & 42 & 91,3 & 4 & 8,7 \\
Straight forward & 10 & 21,7 & 36 & 78,3 \\
\hline
\end{tabular}

When we examined the advertisements analyzed in this study with regards the message tone, it was observed that "serious" (87\%) and "straightforward" $(78,3 \%)$ tones were most frequently preferred (Table 3).

\section{b. Choice of words}

Table 4: Distribution of Copy Characteristics in Social Advertisements

\begin{tabular}{|c|c|c|c|c|}
\hline $\begin{array}{l}\text { Choice of } \\
\text { Words }\end{array}$ & \multicolumn{2}{|c|}{ Non-exist } & \multicolumn{2}{|l|}{ Exist } \\
\hline & Frequency & $\%$ & Frequency & $\%$ \\
\hline Campaign name & 36 & 78,3 & 10 & 87 \\
\hline Slogans & 30 & 65,2 & 16 & 34,8 \\
\hline Tag Lines & 16 & 34,8 & 30 & 65,2 \\
\hline Copy & 5 & 10,9 & 41 & 89,1 \\
\hline
\end{tabular}

When we examined the use of copy characteristics in social advertisements, it was found that (87\%) included the name of the campaign, $(34,8 \%)$ included the slogan, and $(65,2 \%)$ included the tagline (Table 4). It was also observed that $(89,1 \%)$ covered the advertisement copy. When we consider the fact that the social advertisements subject to the analysis took place in printed media, it is clear that there is a need for explanatory copy at such high rates. 
Moreover, the communication attempts for the purpose of providing information are of significance in social advertisements.

\section{c. Format}

Table 5: Distribution of Format used in Social Advertisements

\begin{tabular}{lcccc}
\hline Format & \multicolumn{2}{c}{ Non-exist } & \multicolumn{2}{c}{ Exist } \\
\hline \multirow{2}{*}{ Illustrations } & Frequency & $\%$ & Frequency & $\%$ \\
Graphics & 42 & 91,3 & 4 & 8,7 \\
Color & 45 & 97,8 & 1 & 2,2 \\
Picture & 18 & 39,1 & 28 & 60,9 \\
\hline
\end{tabular}

When we examine advertisements subject to the analysis with regards the stylistic structures, it was observed that more than half $(60 \%)$ were colored. In addition, the use of photos was largely preferred $(84,8 \%)$ (Table 5).

Forty six social advertisements included in the study were analyzed in terms of structure, level and type of positive and negative emotional appeals. Negative appeals were investigated under three sub-categories including fear appeal, guilt appeal and provocation appeal. Positive emotional appeals were investigated under the following sub-categories; nostalgia appeal, humor appeal, warmth appeal and sexual appeal.

Table6:Distribution of Negative Emotional Appeals by Structures

\begin{tabular}{ccccccc}
\hline Structure & \multicolumn{2}{c}{ Fear appeal } & \multicolumn{2}{c}{ Guilt appeal } & \multicolumn{2}{c}{ Provocation appeal } \\
& Count & $\%$ & Count & $\%$ & Count & $\%$ \\
Visual & 1 & $8,3 \%$ & 4 & $12,9 \%$ & 5 & $\mathbf{1 0 0 , 0 \%}$ \\
Verbal & 9 & $\mathbf{7 5 , 0 \%}$ & 13 & $41,9 \%$ & - & - \\
Both & 2 & $16,7 \%$ & 14 & $\mathbf{4 5 , 2 \%}$ & - & - \\
Total & 12 & $100,0 \%$ & 31 & $100,0 \%$ & 5 & $100,0 \%$ \\
\hline
\end{tabular}


The structure of negative emotional appeals, including fear, guilt and provocation appeal was analyzed under three sub-titles. According to the results of analysis, the fear appeal is included in verbal structure in $(75 \%)$ of the social advertisements, in both visual and verbal structure in $(16,7 \%)$ and only in visual structure in 8,3 percent.

In $(45,2 \%)$ of the social advertisements with guiltiness appeal, this type of appeal was used in both verbal and visual structure. The rate of use in verbal structure was $(42,9 \%)$ whereas the rate of guiltiness appeal included in the visual structure was 12, 9 percent.

Provocation appeal has the lowest frequency in negative advertisement appeal. It was seen that totally, 5 social advertisements had provocation appeal. Provocation appeal appears in visual structure in social advertisements.

Table 7: Distribution of Negative Appeals by Level

\begin{tabular}{lcccccc}
\hline Level & Fear & \multicolumn{3}{c}{ Guilt } & \multicolumn{3}{c}{ Provocation } \\
\hline \multirow{2}{*}{ Never } & Count & $\%$ & Count & $\%$ & Count & $\%$ \\
Somewhat & 1 & $8,3 \%$ & - & - & - & - \\
Much & 5 & $41,7 \%$ & 5 & $16,1 \%$ & - & - \\
A Great Deal & 6 & $50,0 \%$ & 25 & $80,6 \%$ & - & - \\
Total & - & - & 1 & $3,2 \%$ & 5 & $100,0 \%$ \\
& 12 & $100,0 \%$ & 31 & $100,0 \%$ & 5 & $100,0 \%$ \\
\hline
\end{tabular}

Table 7 presents the distribution of negative emotional appeals by level in social advertisements. The level of fear in social advertisements with fear appeal is "much" at rate of 50 percent. The case of neither low nor high fear rates in social advertisements with fear appeal is 41,7 percent. When we examined guilt appeal, it appears that the highest rate is again "much" by 80,6 percent. The next is the level of "somewhat" at rate of 16, 1 percent. The level of the provocation in social advertisements with provocation appeal is "a great deal" at rate of 100 percent. 
Table 8: Distribution of Positive Emotional Appeals by Level

\begin{tabular}{lcccccccc}
\hline & \multicolumn{2}{c}{ Nostalgia } & \multicolumn{2}{c}{ Humor } & \multicolumn{2}{c}{ Warmth } & \multicolumn{2}{c}{ Sex } \\
Level & Count & $\%$ & Count & $\%$ & Count & $\%$ & Count & $\%$ \\
Never & - & - & 8 & $72,7 \%$ & - & - & - & - \\
Little & - & - & 1 & $9,1 \%$ & 2 & $\mathbf{6 6 , 7 \%}$ & - & - \\
Somewhat & 1 & $100,0 \%$ & 2 & $18,2 \%$ & 1 & $33,3 \%$ & 2 & $66,7 \%$ \\
Much & - & - & - & - & - & - & 1 & $33,3 \%$ \\
Total & 1 & $100,0 \%$ & 11 & $100,0 \%$ & 3 & $100,0 \%$ & 3 & $100,0 \%$ \\
\hline
\end{tabular}

In the study, level of positive emotional appeals was graded as "a great deal, much, somewhat, little and never". The level of nostalgia appeal is "somewhat" at rate of 100 percent. Level of humor appeal is never in $(72,7 \%)$, somewhat in $(18,2 \%)$ and little in 9, 1 percent. For level of warmth, little corresponds to (66.7\%) and "somewhat" is at 33,3 percent. The level of the sexual appeal, the last appeal of the category, is "somewhat" at rate of (66, $7 \%$ ) and "much" at rate of 33,3 percent.

Table9:Distribution of Positive Emotional Appeals by Structure

\begin{tabular}{lcccccccc}
\hline Structure & \multicolumn{2}{c}{ Nostalgia } & \multicolumn{2}{c}{ Humor } & \multicolumn{2}{c}{ Warmth } & \multicolumn{2}{c}{ Sex } \\
& Count & $\%$ & Count & $\%$ & Count & $\%$ & Count & $\%$ \\
Visual & 1 & $100,0 \%$ & 3 & $27,3 \%$ & 3 & $100,0 \%$ & 2 & $66,7 \%$ \\
Verbal & & & 2 & $18,2 \%$ & & & & \\
Both & & & 6 & $54,5 \%$ & & & 1 & $33,3 \%$ \\
Total & 1 & $100,0 \%$ & 11 & $100,0 \%$ & 3 & $100,0 \%$ & 3 & $100,0 \%$ \\
\hline
\end{tabular}

Table9 presents us the distribution of positive emotional appeals by structure. Nostalgia appeal is included in visual part of the social advertisements by 100 percent. Humor appeal takes place in both visual and verbal part of the social advertisements by 54,5 percent. Just as the case in nostalgia appeal, the warmth appeal is contained in the visual part of the social advertisements at rate of 100 percent. When we examined sex appeal, it could be observed that this appeal appeared in visual part of the social advertisements at rate of 66, 7 percent. 
Table 10: Distribution of Negative Emotional Appeals by Type

\begin{tabular}{lcc}
\hline \multicolumn{1}{c}{ Negative Emotional Appeals } & Frequency & \% \\
\hline Physical fear & 11 & 23,9 \\
Social fear & 1 & 2,2 \\
Reactive guilt & 6 & 13,0 \\
Anticipatory guilt & 3 & 6,5 \\
Existential quilt & 22 & 47,8 \\
Violation of the social and cultural taboos & 5 & 10,9 \\
\hline
\end{tabular}

Fear, one of the negative emotional appeals, was analyzed in comparison with guilt and provocation appeals. It was found that $(23,9 \%)$ of the social advertisements with fear appeal were related with physical fear and (1\%) was related with social fear. Of social advertisements with guilt appeal, type of existing guilt was present in (22\%), reactive guilt in $(6 \%)$ and anticipatory guilt in 3 percent. It was found that $(5 \%)$ of the provocation type used in social advertisements with provocation appeal was the violation of the social and cultural taboos.

Table11: Distribution of Negative Emotional Appeals Depending on their Types

\begin{tabular}{lcc}
\hline Positive Emotional Appeals & Frequency & \% \\
\hline Patriotism & 1 & 2,2 \\
Comic idea & 2 & 4,3 \\
Irony or offensive humor & 9 & 19,6 \\
Warmth of children & 3 & 6,5 \\
\hline
\end{tabular}

Another category examined in this study is the distribution of positive emotional appeals by type. The type of nostalgia found in social advertisements with nostalgia appeal is patriotism at rate of $(2,2)$ percent. Humor appeal stands out with two different types in social advertisements. The first one is irony or offensive humor at rate of $(19,6 \%)$ and the second one is funny ideas at rate of 4, 3 percent. Among types of warmth appeal, the type of children is used at rate of 6,5 percent. 


\section{Communication of advertised company/brand}

Table 12: Distribution of Communication of Advertised Company/Brand Used in Social Advertisements

\begin{tabular}{lrrrr}
\hline & \multicolumn{3}{c}{ Non-exist } & \multicolumn{3}{c}{ Exist } \\
\hline & Frequency & $\%$ & Frequency & $\%$ \\
Company name & 1 & 2,2 & 45 & 97,8 \\
Company logo & 1 & 2,2 & 45 & 97,8 \\
Phone number & 16 & 34,8 & 30 & 65,2 \\
Web site & 33 & 71,7 & 13 & 28,3 \\
Email & 43 & 93,5 & 3 & 6,5 \\
Sponsorship & 44 & 95,7 & 2 & 4,3 \\
Supporter & 36 & 78,3 & 10 & 21,7 \\
\hline
\end{tabular}

Almost all social advertisements included in the analysis have the corporate name and logo. It was found that those with phone numbers $(65,2 \%)$ were still higher than those with web addresses $(28,3 \%)$. Few companies included the e-mail address $(6,5 \%)$. Ones giving place to the supporters $(21,7 \%)$ were higher than those involving the sponsors $(4,3 \%)$ (Table 12).

\section{Results}

Social advertisements are more largely produced by instruction of non-governmental organizations.

Many social advertisements in Turkey are performed by non-governmental organizations. Companies are aware of the fact that they have to be sensitive to social problems and that they should return to the society what they benefit from the society in form of service in order to survive in commercial operations. Many business companies prefer to jointly work with a non-governmental organization within scope of the corporate social responsibilities.

Environment and street children are the most popular ones among the subjects of social advertisements.

The environment and street children are the pioneering subjects in social advertisements. Ten principles of the Global Compact, which is put into force by United Nations, are included 
under titles of human rights, labor standards, environment and anti-corruption. The companies desiring to leverage their reputation in part of social partners cannot ignore the issues such as environment and street children.

\section{The execution style of social advertisements is generally in the form of life style.}

The execution styles in social advertisements consist of lifestyles and the slice of life. The social advertisements in the form of lifestyles and the slice of life are more easily adopted by the audience.

\section{The message tone used in social advertisements is serious.}

The message tone used in social advertisements is serious and straightforward. Although advertisers prepare social messages compatible with the lifestyle, it is possible to speculate that the tone in substantial part of messages is serious.

\section{Name of the campaign and a copy is included in most social advertisements}

The stylistic structure in advertisements is colored. Moreover, photos are largely preferred. The increasing visual tendency by people may make the use of photos compulsory. If a very effective photograph is present and it conveys a social message, the advertisement message can be communicated to the target audience without use of any additional text.

Fear appeal is in verbal form in social advertisements. The social advertisements with guilt appeal use this type of appeal both in verbal and visual form.

\section{Nostalgia appeal is included in visual part of social advertisements.}

Humor appeal is included in both visual and verbal part of social advertisements. Just as the case in nostalgia appeal, warmth appeal takes place in visual part of social advertisements. When we consider sex appeal, it can be seen that this type of appeal is in the visual part of social advertisements. Depicting sexuality with visual elements, rather than with message, can be more applicable method.

\section{The level of fear and guilt in social advertisement is high.}

The level of fear and guilt in the social advertisements with fear and guilt appeals is high. It is possible to suggest that fear and guilt are more commonly preferred in comparison with 
positive emotional appeals as a way of leading changes and increasing awareness on subjects of social campaigns. Although provocation appeal is very commonly used in social advertisements, the level is high in the social advertisements with provocation appeal.

The level of nostalgia appeal in social advertisements is average. The level of humor is low in humor appeal. It is possible to suggest that humor is not preferred in Turkey in messages about serious issues. The level of warmth in warmth appeal, which may be easily used in issues such as maternal and child health and animal rights, is quite low. It should be necessarily reminded that the sense of warmth may play a positive role in changing behaviors. The level of sexuality in social advertisements with sex appeal is average.

\section{Humor appeals are not preferred.}

Humor is not a strategy preferred in social advertisements in Turkey. The rate for the use of warmth appeal is quite low. The use of sex appeal is at average level. Almost all social advertisements included in the analysis have the corporate name and logo. Those with phone numbers were still higher than those with web addresses. This finding may be due to the fact that enterprises with social advertisement do not have web page. In relation with this finding, number of companies with e-mail address is low. Companies giving place to the supporters in social advertisements were higher than those involving the sponsors.

In this part of the study, the distribution of the creative production applications in social advertisements and accordingly the emotional appeal is revealed out. In the future study, attitudes of recipients towards social advertisements and the establishments portrayed in these advertisements and their intentions towards the behaviors wanted to be changed/reinforced in the social advertisement will be examined. 


\section{References}

Belch, G. ve M.A. Belch (1995). Introduction to Advertising\& Promotion an Integrated Marketing Communication Perspective. 3rd ed. Chicago: Irwin.

Berkman, H. W. ve C. Gilson (1987).Advertising, Concepts and Strategies.Consulting editor, M. Joseph Sirgy. 2nd ed. New York, N.Y. : Random House

Bettinghaus, E. P.ve M. J. Cody (1987).Persuasive Communication. 4th ed. N. Y: Holt, Rinehart and Winston.

Davies, M. (1993).Developing Combinations of Message Appeals for Campaign

Management.European Journal of Marketing.27(1).

Drumwright, M.E., P.E. Murphy (2001) Corporate Societal Marketing, Handbook of

Marketing and Society, Paul Bloom \& Gregory T. Gundlunch (edit.)Sage Pub. USA.

Gürgen, H. (1987) “BirHalklaİlişkilerFaaliyetiOlarakSosyalReklamlar” Ankara: I.

UlusalHalklaĭlişkilerSempozyumu.

Kaptan, S.S. (2003). Social Dimension of Advertising, First edition. New Delhi :Sarup\& Sons.

Karasar , N. (2002).Bilimsel Araştırma Yöntemi. Ankara: Nobel Yayın Dağıtım Ltd.Şti.

Kotler, P., N. Roberto, N. Lee (2002). Social Marketing, 2nd ed. Thousand Oaks, Calif.: Sage Publications.

Kotler, P\& Lee, N (2005). Corporate Social Responsibility, New York, NJ: John Wiley \& Sons.

Lane, W. R. Whitehill King, K. J. Russell T ( 2005). Kleppner's Advertising Procedure.

16th ed. Upper Saddle River, N.J. : Pearson/Prentice Hall

Manrai, L.A., V. C BroachJrve A.K., Manrai, (1992). Advertising Appeal and

Tone:Implications for Creative Strategy in TV Commercials.Journal of Business Research. 25.

Moriarty, S.E. (1991). Creative Advertising : Theory and Practice. 2nd ed. Englewood Cliffs, N.J. : Prentice Hall

O’Connora, A., Shumateb, M. \& Meister, M. (2008) Walk the line: Active Moms Define Corporate Social Responsibility. Public Relations Review .34.

Öztürk, M.C. (2009) “SosyalBoyutluReklamlar”, edit: SahindeYavuz, ReklamınToplumsalYansımalarıveYeniReklamBiçimleri, Ankara: UtopyaYayınevi.

Wells,W. J. Burnett ve S. Moriarty (2000).Advertising Principles and Practice.5th ed., Upper Saddle River, N.J. : Prentice Hall 

Volume: 3 - Issue: 3 - July - 2013

Yılmaz, R. A. (1999). DuygusalÇekicilikliReklamlarınIletişimEtkileri.Eskişehir: AnadoluÜniversitesi. YayımlanmamışDoktoraTezi. 